TAMAR JEFFERS MCDONALD

\title{
Reviewing Reviewing the Fan Mags
}

\begin{abstract}
On June 2, 1933, trade daily the Hollywood Reporter announced it was inaugurating a new column, Reviewing the Fan Mags. The section appeared sixty-five times over the next twelve months, eventually surveying 145 magazine issues. The column then ceased as suddenly as it had begun, this time without fanfare. In beginning the section as a new service for readers, the editor, W. R. Wilkerson, had attested that fan magazines were important to the film business. What happened in that year, then, to make Wilkerson decide to abandon the coverage of the movie-magazine contents and ostensibly reverse his views about their utility? This article first examines the contexts, contents, and style of the Reviewing the Fan Mags section before considering the circumstances around its cancellation.
\end{abstract}

KEYWORDS: fan magazines, trade papers, Hollywood, Production Code, gossip

The front page of trade daily the Hollywood Reporter for June 2, 1933, sported the customary mixture of industry comings and goings, casting and production updates, op-ed, and actual news. The Tradeviews column, as usual written by the Reporter's owner and editor in chief, W. R. "Billy" Wilkerson, here introduced the inauguration of a new service for his readers, a column, Reviewing the Fan Mags, that would begin in the issue. 
Reviewing the Fan Mags appeared sixty-five times over the next twelve months, eventually surveying 145 issues of various fan periodicals, including Movie Mirror, Modern Screen, New Movie, Hollywood Movie Novels, Silver Screen, Screenland, and Photoplay. The Reviewing column then ceased as suddenly as it had begun, this time without fanfare, with the last section appearing on June 6,1934 . It was not until almost a whole month later that Wilkerson acknowledged, again via Tradeviews, that his journal had definitely ended its coverage of the movie magazines, citing the "low level" of the fan periodicals' contents as his motive. ${ }^{1}$

Back in June 1933, when the column started, Wilkerson had affirmed the importance of overseeing the work of the movie mags: "Motion pictures need fan magazines. They are great box-office builders, exceptional star builders, are of great help in selling the picture business, as a whole, to the public. $[\ldots T]$ he better they are devised for fan consumption, the greater the help to the industry." 2 Yet only twelve months later, the same column thundered: "[S]omething should be done about this growing evil, especially in the face of present conditions ... the sort of stuff that these magazines are $[s i c]$ printing must be injurious in the minds of decent people, both to the stars and to the pictures in which they appear."3

What had happened in that year to make Wilkerson decide to abandon the coverage of the movie-magazine contents and ostensibly reverse his views about their utility? This article examines the contexts, contents, and style of the Reviewing the Fan Mags section before considering the circumstances around its cancellation. In doing so it aims, first, to acknowledge the column as a fascinating resource for the film-history scholar by underlining the wide range of information-and topical assumptions - that the section reveals about contemporaneous movie magazines as well as about the connections of such publications to the trades, studios, stars, and 
fans. It then seeks to shed light not only on this somewhat incongruous, twelve-month foray of the business-minded trade paper into the fan magazines' giddier world of celebrity love affairs, fashion, and gossip, but also on the topical perception of what fan magazines were meant to $d o$ and $b e$ against a backdrop of looming change for the entire movie industry.

\section{TRADES VERSUS FANS}

The Hollywood Reporter was founded in September 1930, and from its inception dedicated itself to delivering "Today's Film News Today," as its strapline put it. This meant relaying information about business deals, new film castings, studio contracts newly signed or cancelled, and, sometimes, exhibition reports, detailing which picture was opening at or moving to a particular theater. In addition, there was always room for Wilkerson's opinion column, gossip from the Rambling Reporter, and regular updates from adjunct entertainment areas, the legitimate stage, and radio. ${ }^{4}$

While Hollywood largely accepted the new trade paper, it was not universally welcomed: the editors of its venerable New York rival, Variety, were first piqued at the new trade's encroachment on what had been their territory and then outraged that the Reporter seemed to be stealing their actual copy. In late December 1931, the New York weekly sued Wilkerson's paper for “news lifting” (alleging the Reporter's operative in New York wired Variety's Hollywood news to his own office in Los Angeles). Exploiting the inevitable delays inherent in Variety's weekly publication schedule, the Reporter was scooping its rival simply by printing its findings on a daily basis. ${ }^{5}$ Writing in 1961, journalist Ezra Goodman noted that Variety's next move "to combat the upstart Hollywood Reporter" was to start a rival publication, Daily Variety. ${ }^{6}$ 
Interestingly, Daily Variety began publishing in Los Angeles in September 1933; it is possible, then, that one of the impetuses prompting Wilkerson to begin to survey the fan publications each month in his trade from June that year was the desire for product differentiation, giving readers something extra to retain their loyalty ahead of its older rival introducing a West Coast version. Certainly, this would help explain why, given the Hollywood Reporter's remit to cover, as enumerated above, all the important elements of the movie business in Hollywood, Wilkerson now turned his attention to the contents of far more frivolous fan publications, part of a print business run largely from New York. Indeed, his initial decision to devote space to the activities of the fan magazines might be more surprising than that this focus should be short-lived.

Furthermore, in paying serious and positive attention to the fan publications, the Hollywood Reporter was going against trade journal practice: Variety, Film Daily, Motion Picture Herald, and others generally treated the fan mags with a high degree of scorn for their diet of star-focused gossip. For example, in 1930 Variety had commented on the magazines' increasing tendency to print photographs of "gams" and "undies" and noted that this habit was worrying studios, since it frequently misrepresented the films ostensibly being promoted, which were not nearly as "peppery" as they were thus made to seem. ${ }^{7}$ The newspaper further denounced the veracity of the stories in such magazines, calling the writers who heralded divorces as "the world's riskiest prophets, because their prophecies are in print." ${ }^{8}$ Meanwhile, Film Daily sought to praise the editor of New Movie because he, unlike all the others in charge of such periodicals, had shown "a fan mag really can amount to somethin'."9 
But Wilkerson saw both industries as inextricably linked, with the periodicals' fate both running parallel to and also potentially affecting that of film products. Eight days before the launch of the new fan magazine review "service," the Hollywood Reporter's main headline had demonstrated this intertwining: "BIG FAN MAGAZINE DROP. Subscription and Newsstand Sales Flop Like Film Grosses. Modern Screen New Leader." 10 The headline story itself, conversely, sought to ameliorate the significance of the link between magazine subscription and movie attendance, stating, "Not that they go hand in hand to too great an extent," 11 but the full article went on to give, and to consider, the new subscription figures for fourteen movie publications instead of focusing on the parallel industries, and Wilkerson's own Tradeviews commented more fully on this angle of the story. The column firmly asserted the connection between ticket and magazine sales once more: "The astonishing drop in the circulation of fan magazines may be attributed to the same drop in ticket sales in the picture business and for the same reason-LACK OF SHOWMANSHIP."12

In discussing the decline in both ticket sales and movie magazines, Wilkerson asserted that the drop was not attributable to the Depression but had resulted because both industries had become guilty of inefficient exploitation of "personalities."13 Studios had failed to make films with interesting enough stars, while the publishers similarly "have not been printing books of sufficient interest to attract subscriptions and news stand sales." ${ }^{14}$ Wilkerson's next paragraph again laid out his firm belief in the intertwined fates of the movie and magazine businesses: "We call attention to the above simply because fan magazines are a big part of the picture business: they sell a lot of tickets, [and] they are one of the greatest assets in the dissemination of information— good and bad—if they will only disseminate it." ${ }^{\prime 15}$ The Tradeviews comment on magazines' role in ticket selling is a straightforward one, but the 
observation about information dissemination requires context. By June 1933 the Hollywood trade journals, the Hollywood Reporter itself, as well as Variety, Motion Picture Herald, Film Daily, and even monthlies like American Cinematographer, had been attacking the fan magazines for about a year around two main critical points: the fans' wayward treatment of film reviews and their introduction of increasingly sensationalist material.

The trade writers bitterly complained about the magazines' film reviewing style, which tended to give away plot details, putting off audiences via spoilers, either about the story or, at times, more technical secrets. For example, two exhibitors wrote to Motion Picture Herald to protest about fan magazines' stories detailing how the monsters in King Kong (1933) had been made and filmed: One complained, "Fan magazines are doing more to wreck the show business than any other thing I know of [...] Several of my patrons told me they didn't care to see this one as they had been reading how they made it and it would be too mechanical."16 The second stated, "A technical and mechanical masterpiece. Of course, the 'Fan' magazines have taken a lot of the kick out of it, but it's first rate entertainment.",17

Even more provoking, the trades insisted, was the fan magazines' penchant for printing reviews that had clearly been written before, or even entirely without, the reviewer seeing the film. ${ }^{18}$ The trade press sarcastically reported incidents where actors praised by the fan mags were not even in the film in question. This practice does indeed seem to have been widespread but was perhaps not as topical as trade writers believed; for example, two years before, the Screenland review of The Bat Whispers in 1931 praised Zasu Pitts ("grand as usual") despite the actor not being in the cast. ${ }^{19}$ 
Variety reporters in particular also deplored what they saw as a new accent on the scandalous appearing in the fan magazines from 1930 onward, reporting on the movie magazines' muckraking as if it were a brand new aspect of fan-magazine style. However, a quick survey of the history of the fans indicates this was not the case..$^{20}$ The first fan publication, Motion Picture Story Magazine, was launched in February 1911; as its title indicates, it set out to retell the narratives of the latest motion pictures, illustrated with stills from the films. By the end of same year, another publication had begun in direct competition to Motion Picture Story Magazine, Photoplay. Motion Picture Classic was launched in 1915, and within a very short time, movie magazines proliferated, until, as Anthony Slide notes, by the 1920s there were around twenty major fan publications on offer every month at American newsstands, ${ }^{21}$ along with more minor monthlies, weeklies, and quarterlies. Besides the novelizations, standard contents in these early years included photos of the actors, drawings, poems, interviews, contests, letters to the editor, and debates. Although the players were mentioned in the earlier issues, from 1914 onward they became the main focus; public interest can be judged by the number of pages dedicated to questions about actors posed in the Motion Picture readers' inquiry section: twenty-three pages in the August 1914 issue as opposed to twenty-six for the novelizations. ${ }^{22}$ Within three years of its inception as an adjunct to movie narratives, then, the magazine's emphasis was already equally shared with movie performers.

Around this date the covers changed too, ${ }^{23}$ abandoning the previous policy of featuring a photograph from one of the films featured inside and regularizing placing much more emphasis on the single person portrait, which had occasionally been assayed before. ${ }^{24}$ This agrees with Richard deCordova's findings about the shift between the "Picture Personality" and "the Star," 25 with 1914 being the key date for 
the emergence of the latter figure; it also indicates how the intensity of moviemagazine interest contributed to this transition. The two founding fan magazines experimented with different cover formats, with Photoplay trying announcements of contents as early as November 1913, although this was not regularly picked up until the end of the following year. Motion Picture tested this out, too, with the July 1915 cover highlighting contributors as well as contents, including "A Chaplin Feature" that complemented the three separate images of the star under the masthead.

Despite these experiments, until around 1920 the covers of the main contenders consistently showed a painted portrait of one, generally female, star, with little and infrequent copy. Photoplay finally began to consistently headline lead articles in June 1920, when it advertised its series of "Confessions of . . ." articles, beginning with Theda Bara. Screenland, which began publishing in 1920, obviously benefited from the advances made by its longer running rivals and was regularly using cover captions by the following year, when it also seems to have invented a device that was to become a fan-magazine stalwart: the pointed question. Richard deCordova's research has highlighted that Photoplay carefully avoided any mention of the "Fatty Arbuckle affair" in $1921 .^{26}$ The editors of Screenland, however, evinced no such restraint, launching the interrogative trope on the magazine's December 1921 issue cover with the outrageous "Is Virginia Rappe Still Alive? The Most Amazing Message Ever Published-Page 20.”

These titles indicate that salacious headlines were not new to the fan magazines when the trades began to complain about them in the early 1930 s. Although the trade papers perceived material was becoming more risqué- "Fan Mags Get Nasty for Sales"27 — there had actually been no shortage of sensational headlines in the mid- to late 1920 s across most of the major magazines. 
Conforming to deCordova's suggestion that scandal became the dominant mode for the discourse on stars from 1920 onward, ${ }^{28}$ the fan magazine covers began to proffer suggestive text in the twenties. A decade before Wilkerson would insist that fan magazines were there to "sell Hollywood," Screenland, Photoplay, and Motion Picture were proving the opposite, as these publications regularly gave cover space to advertising articles that implied romantic relationships in Hollywood were conducted for mercenary reasons ${ }^{29}$ - or were doomed to fail. ${ }^{30}$ Such pieces did not, then, originate in the 1930s, although they did continue to appear. ${ }^{31}$

Besides taking this cynical view of stars' love affairs, the magazines also occasionally broke other taboos by raising questions about career viability or reimbursement. This kind of article does seem to have originated in the thirties, and was just as potentially upsetting to Hollywood myths - perhaps even more so. By calling into question stars' sustainability ("Is Garbo Through?," Modern Screen, March 1931; “Is Dietrich Through?,” Photoplay, January 1933; “Is Katharine Hepburn a Movie Bubble?," Screenland, September 1933), the fan magazines were at odds with studio rhetoric that inevitably declared each new vehicle a performer's career best. And a further kind of compact seemed broken by the blunt question on the cover of Screenland's August 1934 issue_-“Are the Stars Overpaid?”- especially given, as will be seen below, the topical turmoil in the industry.

Despite this evidence for sensationalist material in the fan magazines being familiar fare long before, reporters for the trades in the early 1930s regularly deplored what they saw as a new accent being placed on the scandalous as the direct result of a circulation war among the fan periodicals, brought about by the arrival on the scene of cheaper, ten-cent magazines. ${ }^{32}$ The trade reporters opined that the internecine fighting arising from competition had created a new demand for candid, unstaged 
photographs - ones that frequently showed stars in unattractive ways, rather than posed pictures ${ }^{33}$ - accompanied by a concomitant increase in sensationalist reporting. ${ }^{34}$

Given this negative stance toward the fan magazines, overt statements in praise of such periodicals before Wilkerson's May 25, 1933, intervention were much rarer and significantly more likely to appear in advertising rather than editorial sections, meaning that they represented the view of the studios, who paid for the space, rather than editorial staff. Two one-page ads that ran in Motion Picture Herald for MGM provide typical examples. The first, an advertisement for two Jean Harlow pictures, commented about the fan magazines that "they're a good barometer of popularity," 35 while the second-ironically, given the simultaneous critique elsewhere in the trades about the fan magazines' bad reviewing practices - thanked seven of the titles for their comments on a Lee Tracy picture, since "millions of fans will read these great reviews." ${ }^{\circ 6}$

In asserting, then, that the fan magazines were adept at getting movie information out to audience members, and that this could be good for business, Wilkerson was adopting what was contemporaneously an unfashionable position. It was clearly one that he was prepared to indulge further, however: Tradeviews, introducing Reviewing the Fan Mags on June 2, 1933, asserted: "FAN magazines have played such an important part in the building of this business and will continue to influence many of their readers one way or the other on pictures, the personalities in them, etc., that in future the Hollywood Reporter will review the activities of these publications singly and in group, just as fast as their issues are made available." 37 Wilkerson's column further noted that the new reviewing service would concentrate on two main points within the magazines, seeking first "to give our readers a brief 
outline of the entire contents of each magazine." 38 Wilkerson seemed here to be tapping into the contemporaneous awareness of the magazines' focus on overly fulsome or erroneous film reviews and on sensational star stories. Flagging instances of these infractions to Reporter readers would then be a service, as it would alert them to negative publicity, perhaps allowing remedial measures to be taken.

It is not so easy, however, to see the utility of the second element that Wilkerson assured would be checked in the magazines surveyed each time. This is the issue of free space, which the Tradeview column explained thus: "Naturally there is a fight on by the publicity departments of all the studios for space, volume and position in fan magazines, for interviews for their stars, for favourable notices on their activities, and on the finished pictures. This space is free and, because of it, there is a fight to secure as much as possible. [....W]e will also measure up the free space given to each studio in the hope of stirring up a little more fight on the part of the publicity staff to crash through with more and better space." 39 This paragraph provides interesting information for scholars interested in both film and in periodicals. Leafing through a movie magazine, one tends to notice the most eye-catching film advertisements, fashions, or star profiles, but this statement from Tradeviews demands that all space inside a magazine be reevaluated. There was paid space—what the studios purchased to announce a new film or manufacturers bought to attract attention to their products - and then there was free space — the "stuff" that made up the rest of the magazine and ostensibly seems to be its reason for existence.

To learn that this free space was planned out and allotted not because of particular interest in this or that star, film, or issue by a writer or editor, but often because this or that studio had supplied compelling or copious enough copy, overturns many assumptions about such publications. Confirming this to his readers - industry 
insiders who presumably knew how the magazines derived their copy—Wilkerson then undertook to reveal which studios had the most effective publicity agents, adept at getting their films and stars into the magazines through providing the materialeither pictorial or textual—-for interesting stories to be written around them.

True to his word, Wilkerson ensured that, from its first appearance, nearly every section of Reviewing the Fan Mags charted the allotment of this free space to the various studios. ${ }^{40}$ The inaugural section looked at three magazines, covering the July 1933 issues of Picture Play, Screenland, and Screen Book. ${ }^{41}$ By its measurements, MGM was the studio that received the most free space in each of these, beating its nearest rival for square inches generally by about a third, with Screenland being granted half as much (1060 square inches) as the next studio, Paramount (580 square inches). Further research would be necessary to ascertain how the measurements were worked out, and whether both photographs and text counted, but in drawing attention to the importance of "space, volume and position," the June 2 Tradeviews column underlined the importance of analyzing the placement of items in the magazines and not just their contents alone.

While the information about the allotment of free space is provocative, it was only one of the regular items of data recorded in each issue of the Reviewing section. The same template was adhered to almost every time, providing, in order: the title of the magazine; the number of pages per issue, given as " $n$ pages and cover"; the star or stars featured on the "cover display," generally with her/his studio mentioned; the "Publicity Space (Approximate)"; and then the contents. This latter section was the longest, with mentions made of the best and any bad pieces, and an overall comment on the quality of the particular issue. Articles were frequently mentioned by title, and/or authors were mentioned on topics, and/or stars featured were listed. In this way 
the reader was given a quick but fairly full account of what was in each issue with which Reviewing dealt.

As noted, the amount and range of data in the year's worth of Reviewing material provides an exciting resource for movie magazine and film scholars. The template followed by the column each time provides a large amount of information that can be used in various ways. For example, the lists of the cover star indicate one form of contemporaneous popularity that can be checked against others, such as Quigley's Top Ten Moneymaking Stars, or Academy Award winners, in order to complicate ideas about early 1930s celebrity. Thus, it is no surprise to find stars such as Joan Crawford and Jean Harlow on the front covers of the magazines, but the year's worth of data also reveals this prominence being afforded to Lillian Bond, Frances Dee, Sally Eilers, and Pert Kelton, names not nearly so well-known now. Furthermore, while Harlow and Mae West remain associated with the thirties and would seem dominant stars of that period, it is perhaps unexpected to find Katharine Hepburn is the star who featured on the most covers: eleven across the entire year of the survey. West and Harlow had nine and six covers, respectively. Although Hepburn may now be more associated with films of the $1940 \mathrm{~s},{ }^{42}$ it is an important corrective to find her possessing such star power in 1933-34, even if not all the material printed on her inside the magazines was entirely positive. ${ }^{43}$

Furthermore, following up on the free-space notion, it would be interesting to research whether a correlation operated between square inches freely given and space paid for by studios, which might mean a quid pro quo system operated, or suggestions of understandings between specific magazines and studios existed that might explain why some seemed favored over others. Anthony Slide suggests this might have been the case in noting that Katharine Albert had been a feature writer at MGM before 
joining the ranks of fan-magazine writers, and that her bias was usually toward reporting on stars from that studio. ${ }^{44}$

\section{STORIES SWELL-AND NOT SO SWELL}

Besides this type of interesting but largely neutral data, most of the text of Reviewing the Fan Mags was devoted to subjective points, such as best and worst pieces. Commentary on the issues reviewed awarded both criticism and plaudits in about equal measure throughout the entire year of its publication: this is significant because it counters Wilkerson's later claim that he ended the section because of a decline in the standard of magazine articles.

Before examining the more subjective writing, I must acknowledge that the author of the Reviewing column was anonymous. Since Reviewing seems to have a coherent voice, lacking evidence to the contrary, I am assuming a single author and referring to her/him. ${ }^{45}$

The reviewer always seemed happy to point out individual items in the magazines that were well done; s/he often praised pieces that were amusing ("Elizabeth Wilson, 'Their Beach Behavior' is lots of fun"46), well written ("a fine, clever, character study of Max Baer" ${ }^{\prime 7}$ ), or well handled (Leslie Howard was deemed to have been "interviewed intelligently" by July 1933 's Picture Play ${ }^{48}$ ).

Seeming acutely aware of a Platonic ideal of a fan magazine article, the reviewer always signalled when a specific issue approached this goal: Elizabeth Wilson, journalist for Silver Screen, often received commendation, and one piece by her was hailed as "a swell example of good fan magazine writing." 49 Similarly, a story on Charles Laughton in Motion Picture for January 1934 was given high praise as "one of the best yarns ever published in a fan magazine or any other type of magazine." ${ }^{50}$ But on occasion praise was also awarded to entire issues; as when, for 
example, the Reviewer announced, "And here is a magazine that IS a magazineSilver Screen for January ... every yarn in the book is a HIT and every writer has an inspired typewriter,"51 or similarly enthused, "Movie Mirror, the only film magazine edited from Hollywood, warrants the experiment. The April number is swell. Good stories, good writing, good make-up." 52

While instances of entire issues celebrated for hitting the mark were rare, their identification seems important, as such publications could be taken as exemplars of what the fan magazine could be, and be for: "There is not a word in the August issue of Modern Screen that is not interesting, timely and well written. [... The interviewers are honest, the articles intelligent, and the atmosphere of the whole magazine is a fine example of what the fan mags should strive after in order to sell Hollywood and pictures and personalities to the public." ${ }^{.53}$ This comment toes the Wilkerson line about the fan magazines' reason for existence, the last phrase clearly echoing his comment in the Tradeviews piece announcing the Reviewing column, that movie mags "are great box-office builders, exceptional star builders, are of great help in selling the picture business." ${ }^{\circ 4}$

However, if promoting Hollywood and its stars was seen as the point of the magazines, and evidence of dedication within articles to doing so was what was singled out for praise, was it the opposite that attracted the reviewer's negative comments? Although, as noted above, the allotment of praise and blame was roughly equal in the Reviewing section, it was not the items that "sold Hollywood" that got the column cancelled, so an examination of the types of criticism it dispensed now follows.

Most of the negative comments on issues were quite mild. Sometimes a specific story was criticized for bringing down the quality of the overall issue: one 
article in an "array of good writing and pertinent stories" was said itself to be "neither good writing nor pertinent." ${ }^{, 55}$ Another piece with a scorching headline and tame copy was skewered for its use of the bait and switch: "the story itself has nothing whatever to do with either title or subtitle," pronounced the reviewer of an article that sounded promising but was actually insipid: "Lost — the Gable Wallop.",56

The standard criticism was that an item, or worse, entire issue, was boring, only recycling copy seen many times before. Screenbook's August 1933 issue was dismissed as "slightly drowsy," 57 while Modern Screen for July 1933, merely reflecting mag business as usual, was "somnolently reminiscent." 58 Magazine pretensions to unusual or exclusive articles were on occasion summarily dismissed: “The 'outstanding features' of July's Shadoplay do not outstand very much. They recline rather lazily on very conventional and tried formulae and succeed unusually well in being just usual." ${ }^{, 59}$

Again, whole issues could be condemned, but this seems to be incited by uninteresting, rather than too interesting, scandalous copy. The magazine Movies came in for frequent censure, with the September-October 1933 issue dismissed as "a pretty thin little magazine, with not much of interest in its pages. It seems to specialize mostly in portraits." ${ }^{\circ 0}$ The February 1934 issue was deemed even worse, as it "hardly comes under the head of fan magazines. It is cheap, inexcusably uninteresting and almost a total loss." ${ }^{.61}$ Similarly, Picture Play for December 1933 was found "pretty colorless," 62 while Screen Play the same month "takes a nose dive, with practically nothing in it to keep it from drowning"; it had "a lot of stories" but these were "all a trifle dull, unfortunately." ${ }^{63}$ Not one of the issues reviewed was condemned for containing too much suggestive material, an important point to 
remember given Wilkerson's comments on issue quality at the time the column was terminated.

Interestingly, the harshest criticism directed at items in the magazines judged subpar was that they lacked, or were in bad, "taste." The concept of taste was, as Gilbert Seldes underlined in 1924, ${ }^{64}$ intimately connected with class, and the reviewer's understanding of the categories of good and bad taste, seemingly instinctive, bear this out, being closely allied to notions of etiquette. The contemporaneous conduct authority was Emily Post, who pronounced on this topic in her syndicated newspaper columns and in her frequently reprinted blue books, from the first printing in 1922 onward. While the 1934 edition of Etiquette contains an explicit section on "The Growth of Good Taste in America," more devoted to defining the accoutrements of a well-appointed and gracious home than a discussion of conduct. The section that revealed many of the topical assumptions about taste in the sense in which it was used in Reviewing the Fan Mags (actions, or in the case of the reviewer, writing appropriate to its location, readership, and class) was "The Fundamentals of Good Behaviour," which sketched the general "decencies" of nice people in polite society ${ }^{66}$ It is clear that dicta from this, such as, "A gentleman never discusses his family affairs either in public or with acquaintances," $"$ and "The born gentleman avoids the mentions of names," $" 68$ did not inhabit the same social space as the fan magazines, which contravened both rules and that therefore such publications' constant cataloguing of the famous and their intimate affairs would always seem jarring to gentlefolk. The reviewer, a trade journalist for the Hollywood Reporter, obviously inhabited the Los Angeles mediascape in 1933 and would have been familiar with the format, style, and preoccupations of fan magazines, movie culture, and indeed the trade press, too, but at times, when s/he 
invoked good taste as a reason why a topic should have been avoided, the assumptions driving the censure seemed to derive more from the well-ordered world of Emily Post rather than the hectic newsroom of Billy Wilkerson. ${ }^{69}$

It should be stressed again that by far the highest number of articles receiving criticism in the Reviewing column were censured for being disappointingly dull to the reader, rather than trespassing on taste grounds; however, there were a few articles that earned more serious censure.

\section{"BAD TASTE"}

The Reviewing column's attention to pieces in poor taste was sustained over the entire period of its publication: the first issue so condemned was reviewed in the third appearance of the section on June 8, 1933, and the last occurred in its final outing almost exactly a year later, on June 6, 1934. Overall, there were seven pieces denounced for tastelessness among the 145 issues reviewed in Reviewing's year of operation, and these were distributed among both high and lower selling titles (Motion Picture, Photoplay, Screen Play, Picture Play, and Movie Mirror had one each, while only Modern Screen was deemed guilty of this lapse twice). ${ }^{70}$ A closer look at a few of the articles that earned the tasteless tag may indicate common factors in them and reveal what the authors were doing that was deemed reprehensible.

This kind of criticism first occurred in only the second column in the review of the July issue of Motion Picture. Referring to the article on the supposed feud between actor Lilyan Tashman and columnist Hedda Hopper over each other's claim to be the best-dressed woman in Hollywood, the reviewer asserted the piece ("Lil vs Hedda - What a 'Battle'!") was "too vitriolic to do either side any good, and its relative unimportance only adds to its bad taste."71 The most noticeable feature of the article was the bathetic style of its writing; the male author, John L Haddon, 
underlined the insignificance of the feud and the women engaged in it by couching it in martial language; at one point he compared the women's quarrel to "the far less important conflict in Manchuria." 72 Likening skirmishes over sartorial supremacy to the then-recent military campaign waged by Japan against China served to belittle both the women and, perhaps, Hollywood itself, which justified the reviewer's annoyance.

The very next Reviewing column critiqued another tasteless piece. This was from the July issue of Photoplay, about which the reviewer sniffed: "Photoplay this month is guilty of one of the most beautiful examples of perfect bad taste ever perpetrated ... It is fortunate, however, that the unfunny malice of the thing is equalled by its vapidity." ${ }^{73}$ Examination of the piece reveals the article was attempting to make something out of the familiar jokes about Greta Garbo's large feet and Jimmy Durante's equally outsize nose (figs. 1 and 2). Rather unattractive marionettes were used to represent the two stars, and in the playlet presented, "Footing Jimmy's Bill," 74 they fell in love when they realized her giant foot was the same size as his "schnozzole." The piece relied on reader awareness of both these pieces of (supposed) information about the stars' personal appearances and Garbo's aloof persona, which, it revealed, was entirely due to her fear of being laughed at because of her "number elevens."

\section{***INSERT FIGS 1 and 2 (TOGETHER) HERE ***}

Whether or not the playlet really was indulging in malice rather than just perpetuating a worn joke, it was not unusual in making capital out of Durante's features, at least. The Hollywood Reporter itself carried an advertisement for his film Palooka illustrated by a cartoon of the star with prominently drawn nasal appendage, the word "Colossal!" next to it, and the tagline "with a HEART AS BIG AS HIS SCHNOZ" 
in March 1934—with the ad situated right next to a Reviewing the Fan Mags section. ${ }^{75}$ On this occasion, the bad-taste label would therefore seem to have been a personal judgment by the reviewer rather than an opinion held by the publishers. The same subjective response was also observable in the cases of other items that earned censure. An article in Modern Screen's December 1933 issue on Paulette Goddard, "Can She Beat the Chaplin Jinx?,"76 was dismissed with "isn't in the best of taste." This piece lengthily detailed the disasters that had befallen Chaplin's female costars: "For some reason, tough breaks have beset Charlie's leading ladies.

Disappointments have overwhelmed them. Magnificent picture deals have vanished ... Financial reversals have piled up. Death has hovered near and occasionally reached. Illness has scourged them. Their homes have been robbed, their possessions stolen. And generally speaking their picture careers have led to the squatty little studios on Poverty Row from which few ever emerged."77 The article gave an account of Goddard's character and career to date, offering factors that might save her, but concluded: "Now it's Paulette Goddard's turn. How will she fare? You make the prediction." ${ }^{, 78}$ The bad taste of the article presumably arose because few of the misadventures and accidents that had occurred to costars such as Edna Purviance and Merna Kennedy could realistically be laid at Chaplin's door. The author's aim seems to have been to write a piece undermining Chaplin, but evidence of actual bad behavior was lacking, and there was nothing to prove Chaplin was responsible for any of the problems cited. The piece needed therefore to be couched in an allusive tone that worked through innuendo. Perhaps the reviewer applied the bad-taste tag when the story or its tone was snide?

This supposition seems to be borne out by another piece that prompted the reviewer's ire, “The Strange Case of Miss Morley," by Jeanne de Kolty, from the 
January 1934 issue of Picture Play. ${ }^{79}$ Of this, the reviewer remarked, "if it isn't dynamite, it is certainly in bad taste. ${ }^{, 80}$ De Kolty, announcing herself a former schoolmate of the actor, penned a spiteful little piece, chiefly significant for its barbed tone and lack of actual material. Morley had recently had a baby and not appeared in studio publicity for a period. The journalist chose to interpret this as an indication that Morley's star was on the wane and her career potentially "fading rapidly into oblivion." ${ }^{\prime 1}$ While pretending to care about the actor's well-being, de Kolty managed to get in quite a few hits at her avoidance of the limelight, which, it suggested, bordered on the pretentious: “A possible explanation [for Morley's recent low profile] lies in the fact that Karen's behaviour has resembled that of Greta Garbo's in the last few months. Unfortunately, Karen lacks the glamour of the Swedish star."

Though she assumed a familiar tone, calling the actor by her first name, de Kolty here undermined both Morley's career management and attractiveness. The piece ended with another similar barb that while ostensibly offering solicitude, was actually gleefully gloomy at the actor's seeming dip in popularity: "If the great silence of Miss Morley is truly due to ill health, she deserves nothing but sympathy. However, those close to her agree that she would be wise to explain her position if such is the case, for fans are notoriously fickle and do not like being ignored. Continued silence may prove disastrous to her career. A dissatisfied public does not make box office receipts." 83 The piece confirms the idea that snide articles attracted the reviewer's censure. De Kolty's tone aped concern but her words undermined this (if Morley were ill ...). The comment that the actor should engage again with the press to explain her silence prompts the question of whether she had refused de Kolty an interview, and this malicious article, noticeable for literally being about not commenting, was the result. 
The final article that earned the reviewer's disapproval to be examined here was dismissed for its "glaring bad taste" and provided even more obvious grounds for condemnation. ${ }^{84}$ Unlike the Chaplin and Morley pieces, which resorted to sly insinuation to get their message across, Katherine Albert's article on Joan Crawford, "I'm a Terrible Person," in the April 1934 issue of Modern Screen, offended by not being allusive enough. It laid out its report of the star's ostensibly self-avowed faults clumsily, without recourse to the hinting, sly style of the other items (figs. 3 and 4).

***INSERT FIGS 3 and 4 (TOGETHER) HERE ***

The Crawford piece is the kind of article, not too uncommon, in which a star (allegedly) owns up to everyday normal faults. Such articles are probably intended to narrow the gap between ordinary and extraordinary that stars inhabit and make them seem more like regular audience members and fans. Usually the article writer knows how to slant the piece so that a star's confession of faults comes across as charming. Albert, however, seemed to have missed out on this lesson. Her article began with a rather disingenuous paragraph, the aim of which was to make the succeeding article seem all the more rare: "I've always known Joan Crawford was honest, but I never thought any picture star would talk about her faults. I thought that old Hollywood idea that only one's best side should be shown to the public and that virtues alone should be mentioned was so deeply planted that it could never be uprooted." ${ }^{\prime 85}$ Albert was setting up the novelty of her article, neatly overlooking that such fault pieces were already a standard gambit of the fan magazine. Crawford herself had been mentioned in one such piece, "As They See Themselves," in the July 1930 Picture Play, ${ }^{86}$ while Gloria Swanson, Bebe Daniels, and Sylvia Sidney had owned up to their shortcomings in "Their Million Dollar Defects." $" 77$ This appeared, however, to be the only time in the article that Albert took control of her material. The rest of the article 
was presented as direct quotes from Crawford, without any commentary from the journalist. Crawford aired her insecurities and then psychoanalyzed herself; commenting on her assumption that clever remarks were being made at her expense, she admonished herself, "Now, that's just plain ego!" 88 She used the language of therapy, commenting on her "neurosis" and detailing her attempts to work toward understanding, and thus cessation, of her tics. Without the gloss of contextualization by Albert, however, the confessions seemed outlandish: "But one of my worst faults is cleanliness. Does that sound funny to you? Just normal cleanliness is fine, but for a couple of years I've been neurotic about it. Thank God, I now know what causes itsomething too personal to tell —and when we know about a thing we can at least try to do something to change it." 89 "Something too personal to tell" might be the subtitle of every movie magazine article ever written. The crucial point in such articles, however, is that whatever this something is, it is always revealed to the reader. This Modern Screen piece never disclosed the "something." Albert made a mistake by neither providing an answer, nor editing out the damaging phrases, with the result that Crawford seemed to be acknowledging some dire personal failing, perhaps even a sexual one. Leaving the secret secret both made it seem much worse and went against movie-magazine practice. In this article on Crawford, Albert seemed to have been totally unable to deal with the problems her ostensibly straightforward reporting caused, which made the star seem less approachably human than pathological. The reviewer firmly laid the blame on the writer for this: "The fault lies with Miss Albert, who probably didn't realize that things in print sometimes are worse than the same things said. $" 90$ The reviewer thus acknowledged that the article flouted fan magazine custom: the Joan Crawford piece seems illustrative of a basic misunderstanding by the journalist of the rules of the game. 
It seems then that the bad-taste criticism was often used when a star was being disparaged in a sly_or clumsy_manner. In the column of July 5,1933, decrying “another of those Jimmy Durante-Greta Garbo unfunnies," the reviewer provided an explanation of why this and other such pieces should be condemned, noting it did not "help to sell Hollywood, which is supposed to be the aim and purpose of fan magazines." $" 91$ This quotation, however, suggests that another misunderstanding had occurred, and perhaps not solely by the Reviewing columnist. Wilkerson had praised the fan magazines for their potential to build box office and stars: this was his justification for inaugurating their survey. But fan magazines did not exist to sell Hollywood but to sell themselves, and sometimes — from 1914 onward — this involved peddling gossip items that would attract publicity through scandal-piqued curiosity rather than any more wholesome emotion.

None of the pieces dubbed by the reviewer to be in bad taste seriously suggested the star in focus was wicked or had done anything criminal or immoral: Charlie Chaplin, at worst, it was implied, preferred inexperienced costars and was ruthless in dismissing actors once they became more worldly-wise. Garbo and Durante were mocked for physical attributes, Morley for pretension — and that by an author who could not hide her own animus against the star. Joan Crawford suffered the worst treatment in the article on her because the author did not take the trouble, or perhaps know how, to soften her direct quotes and parse her harsh self-indictments into smoother, more flattering confessions of trivial flaws. But nowhere in the Reviewing column's twelve-month survey does there appear an article that would seem to justify the cancellation of the section.

\section{CONCLUSION}


While, then, the reviewer occasionally accused the fan magazines of publishing material that was in bad taste — and, at least once, with evident justification — the articles in the magazines seemed to be fairly mild, not justifying Wilkerson's scathing attack. Nevertheless, in his July 3, 1934, account of the reason for the column's cancellation, Wilkerson denounced the contents of the current months' periodicals. Taking over the reviewing duties himself, he condemned most of the movie magazines he had seen, noting that "of the ten so far issued for August, only one, namely Screenland, can escape justifiable criticism for 'dirtying up' its contents.",92 He reserved his most harsh, and lengthy, criticism for the month's Modern Screen, however:

Its cover offers "The Story of Gable's First Love," which "reveals" a "hectic romance" that hardly casts credit upon [the star]. Other choice morsels from the table of contents include: “Are You Sick of Hollywood Divorces?" by Dorothy Manners, who asks you to be; “She Ain't No Angel," in which Ruth Biery calls Janet Gaynor "a flirtatious little sex appealist”; “One Girl’s True Hollywood Experiences," with Eva Beryl Tree detailing to Harry Lang her experiences while trying to remain chaste while breaking into the movies [....] and one of the most inexcusably vicious stories we have ever read, "How Long Will Hollywood Protect Harlow?"93

\section{***INSERT FIG 5 and 6 (TOGETHER) HERE***}

This piece on Jean Harlow (figs. 5 and 6), the fallout from which has been carefully detailed by Mary R. Desjardins, ${ }^{94}$ clearly did go beyond the bounds of an error in taste, rehearsing, as Tradeviews notes, "with leering insinuations, all of the gossip it is possible to print regarding her private life." 95 Whether or not it actually was as infamous as the Hollywood Reporter claimed-Harlow does not appear to have sued 
the magazine for libel — the item can clearly be seen as more sensationalist than any published in the previous year, when the Reviewing column was operating. It should be noted, however, that Reviewing had disappeared the month before the Modern Screen August issue was published; Wilkerson could not claim he had killed off the column because of this specific issue. Yet, as has been explored, none of the contents of the year's worth of issues surveyed matched the Harlow piece for suggestiveness. When assistant editor Frank Pope concluded his July 3 denunciation of the fan magazines, he called for direct action: "Certainly something should be done about this growing evil, especially in the face of present circumstances." It seems context, not content, was actually key to the decision to cancel Reviewing.

A return to the front pages of the Hollywood Reporter clarifies what these "present conditions" were, illuminating why Wilkerson and Pope suddenly felt the need to become hypercritical of the fan magazines and move to dissociate the Hollywood Reporter from them. Reviewing the topical context in which they denounced Modern Screen, Motion Picture, Photoplay, and their ilk points toward an alternative motivation for the repudiation of the magazines for which they called, other than the magazines' supposed breaches of good taste.

Examining the front page of the Hollywood Reporter from May 1934 onward reveals both the escalation of the movement to clean up the movies and Wilkerson's growing awareness of the serious impact this might have on the film industry as a whole. Spread between the main headline stories, smaller items, and the editorial Tradeviews column, the story of Hollywood's capitulation to the Hays Office unfolded across practically every day's issue. On May 31 the main banner headline declared "Catholics on Warpath," 96 with the article asserting that all Catholic bishops in the United States had been instructed to write to the exhibitors in their dioceses 
"demanding a rigid ban on filth." ${ }^{\text {"97 }}$ Meanwhile, in Tradeviews, Wilkerson urged producers to mobilize to defend their pictures and themselves:

DEAR MR PRODUCER

This war against "filthy pictures" is being fought on every front AND YOU MUST GET INTO ACTION.

If you are guilty of the charges (and we believe you are NOT) then clean your house IMMEDIATELY. If you deny the guilt, then YOU MUST start a campaign of your own and start it right now. ${ }^{98}$

This pattern of a news item and its editorial gloss appearing on the same page continued on June 7, with a banner revealing that films by MGM producer Irving Thalberg had been specifically targeted as problematic; Tradeviews again asked the industry what it was going to do about the dirt situation. The June 9 headline informed readers "Cardinal Bans All Pix," 99 stepping up the church protest against Hollywood by mandating all films be avoided, not just proscribed ones; by June 11 a small front-page item detailed that a congressman, Cannon of Wisconsin, had called for legislation to ensure films became more moral, with the representative quoted saying "actors and actresses become hardened to immorality and suggestive conduct."100 June 13 brought Wilkerson's report that he had been talking to various bishops; the following day, Tradeviews revealed that one cleric had admitted to the editor he had been provided with a list of objectionable film material, rather than discovering problems himself, ${ }^{101}$ even as the main headline proclaimed the actors' fury at being denounced by Cannon (“Actors Resent Slurs”). ${ }^{102}$ On June 15 Wilkerson suggested in Tradeviews that a rogue band of "racketeering exhibitors" might be responsible for the smut charges, ${ }^{103}$ while a smaller item reported the spreading of the Catholic picture boycott. ${ }^{104}$ Then, on June 18 Tradeviews approved the plan 
developing among the studios that the best way to protect Hollywood was "to give the reformers nothing to reform." 105

The following day, June 19, the effects of the clean-up campaign could be found all through the Hollywood Reporter, not just on its front page, though it was there too: a news item revealed that the Jewish Conference had joined "the war on dirt," 106 while inside articles noted that the Hays Office was now demanding rewrites and reshoots of Born to Be Bad to remove objectionable material, ${ }^{107}$ and another item delivered the news that, from now on, the board of directors for the MPPDA would be the "final arbiters on all disputed points" concerning studio product. ${ }^{108}$

Dispatches from the front line in the "war on dirt" were now posted throughout all the pages of the trade daily. Although the last column of Reviewing the Fan Mags had appeared only thirteen days before, and it was not therefore beyond possibility that it might be published again, ${ }^{109}$ the amount of attention being devoted to the clean-up campaign obviously impressed Wilkerson sufficiently to kill off the section. Abandoning the idea of blaming the industry's problems on a band of rogue exhibitors, the editors had now found a new target:

Possibly the biggest contributing factor to all this censorship mess can be found in the pages of fan magazines. There are today more than twenty magazines of this type flourishing in this country and spreading the bad word about Hollywood to hundreds of thousands of people. And the people love it, take it as gospel truth, while picture companies seem to feel that the publicity gained from the pictures and interviews printed justifies the means and the end.

Well, it begins to look as if the end were pretty much in sight and that the busy censors are about to take care of it. In reading over some of the statistics cited 
against the picture industry by prominent Church officials, it is quite evident that they were gleaned from reading fan magazines. ${ }^{110}$

The "pictures and interviews" comment here seems to hint at the magazines' use of candids and sensationalist copy that had exercised the trade press in 1933, while the reference to church officials suggests the list of movie peccadillos that the bishops had seen had been compiled, not from the movies themselves, but from the very magazines Wilkerson thought should be selling Hollywood and boosting its products. While the Tradeviews column when announcing the arrival of the new section in June 1933 had asserted that "motion pictures need fan magazines," 111 just over a year later, the situation of the industry had so changed that the same column now repudiated such publications: "There is practically nothing normal, nothing wholesome, nothing uplifting in fan magazines, and the whole industry would be a whole lot better off without the kind of publicity that most of the stuff printed in them offers for public consumption."112 This complete volte-face occurred at a time when Hollywood anticipated significant threats to its freedom and profits, in light of the spreading religious boycotts, the imminence of the code imposition, and Joseph Breen's rise to power.

Wilkerson and Pope were by now urging Hollywood to offer up a whipping boy. By denouncing the movie magazines, the editors perhaps hoped the attention could be taken off motion pictures, and the cheap periodicals that reported on them would become subject to surveillance, even legislation, instead of the movies themselves. The cancellation of the Reviewing column was not then ultimately due to the magazines' low standards but to Wilkerson's need to dissociate himself and what he wanted to advance as his own legitimate publication from those irreparably tainted. 
The initial inauguration and final cancellation of the Reviewing column seem therefore to be predicated on different assumptions about what the fan magazines were meant to $d o$ and to $b e$ : Wilkerson had originally hoped they were there to "sell Hollywood," and while the column's surveillance did not reveal much to the contrary, the changing industry context meant that by the time of its cancellation the fan mags were a scapegoat. Ironically, while the fan magazines would go on to be subjected for a short while to close scrutiny, their writers reduced in numbers to a "White List" of fifty approved scribes who could be counted on to write tastefully, ${ }^{113}$ movie periodicals would not thus be purged of salacious gossip or scandalous innuendo. The fan magazines soon reverted to business as usual-Modern Screen, singled out for Wilkerson's particular censure over its Harlow article, perhaps responded to his attack by featuring the star in a suggestive pose in its December issue of the same year, 1934 (fig. 7). Inside it not only carried the sensational piece touted on its cover, "Why One Star Hates Women!," but also the allegedly anonymized story of the husband of a major female performer, "I Have Been Kept by a Movie Star."114 Scandal clearly continued to sell, and periodicals continued to exploit this. Beyond the fan magazines, other movie publications persisted in printing material that was clearly devoid of good taste, too, as with this tidbit: "Hear tell (in spite of Bob Montgomery's gay denials in the fan mags) that the Montgomery divorce proceedings are a matter of moments. The situation has reached the 'settlement' stage — and it's quite a settlement, from what we gather. Or maybe we should say, 'from what Mrs. M. is going to gather.' [...] So either somebody has a very good lawyer or maybe somebody has a very guilty conscience — or maybe the age of generosity is upon us!" 115 The source of this sly piece of bad taste? The Low Down column of the Hollywood Reporter, appearing on June 29, 1934 - just eight issues after Wilkerson's denunciation of the fan magazines. 


\section{Notes}

All images reproduced with grateful thanks from the collections of the Media History Digital Library, http://mediahistoryproject.org.

${ }^{1}$ Frank Pope, Tradeviews, Hollywood Reporter, July 3, 1934, 4.

${ }^{2}$ W. R. Wilkerson, Tradeviews, Hollywood Reporter, June 2, 1933, 1.

${ }^{3}$ Frank Pope, Tradeviews, Hollywood Reporter, July 3, 1934, 4.

${ }^{4}$ For example, the contents from January 2, 1933, the first issue in the year that Wilkerson inaugurated Reviewing the Fan Mags, were entirely typical, with its first page providing stories on star-studio relations ("Dietrich Sued by Para," "Katharine Hepburn for 'Little Women"”), contractual dealings (“Mervyn LeRoy Signs New Warner Deal," "Radio Frees Ovitz”), theater transfers (“"Sign of Cross' Moving”), and even a health bulletin ("MGM Flu Victims"), besides Wilkerson's own Tradeviews, on this occasion musing about what the new year would bring. The rest of the eight-page issue comprised more studio news, along with gossip from the Rambling Reporter (2), advertising for forthcoming Paramount pictures, and the regular two-page roundup of Pictures Now Shooting (6-7), with the back page being used for overflow news and the latest from New York.

5 ““Variety’ Sues Coast Daily over Alleged News Lifting,” Film Daily, January 6, 1932, 1. See also “"Variety” Charges Hollywood Daily with Stealing Its News Each Wk” [sic], Variety, January 5, 1932, 2; “About News Lifting,” Variety, February 9, 1932, 49; and Ezra Goodman, The Fifty-Year Decline and Fall of Hollywood (New York: Simon and Schuster, 1961), 71. 
${ }^{6}$ Goodman, The Fifty-Year Decline and Fall of Hollywood, 59.

7 “Gams-Undies in Fan Mags Irk Hays," Variety, September 3, 1930, 2.

8 “Film Sobbies Now Compete With Seers," Variety, July 14, 1931, 2.

${ }^{9}$ Phil M. Daly [pseud.], “Along the Rialto,” Film Daily, November 5, 1931, 4.

10 “Big Fan Magazine Drop,” Hollywood Reporter, May 25, 1933, 1.

${ }^{11}$ Ibid.

12 Ibid.

${ }^{13}$ Many established scholars have discussed this issue; see Tino Balio, Grand Design: Hollywood as a Modern Business Enterprise, 1930-1939 (Berkeley: University of California Press, 1996); Thomas Schatz, The Genius of the System: Hollywood Filmmaking in the Studio Era (London: Faber and Faber, 1998); Douglas Gomery, Hollywood Studio System: A History (London: British Film Institute, 2005); Iwan Morgan and Philip John Davies, Hollywood and the Great Depression: American Film, Politics and Society in the 1930s (Edinburgh: Edinburgh University Press, 2016).

${ }^{14}$ Ibid.

${ }^{15}$ Ibid.

${ }^{16}$ Robert K. Yancey, "What the Picture Did For Me" [on King Kong], Motion Picture Herald, July 22, 1933, 71.

${ }^{17}$ Henry Reeve, "What the Picture Did For Me," [on King Kong], Motion Picture Herald, September 16, 1933, 59. For similar complaints, see also Motion Picture Herald, June 10, 1933, 48; July 8, 1933, 30; September 16, 1933, 66; December 16, 1933, 68; and December 23, 1933, 73.

${ }^{18}$ See "Fan Mags Now Faking Reviews and News in Desperate Competitive Fite," Variety, January 17, 1933, 3; "Inside Stuff_Pictures," Variety, September 5, 1933 , 
75; "Fake Reviews of Pix Tops Frantic Competish of Fan Mags to Survive," Variety, September 12, 1933, 3.

19 “Critical Comment on Current Films," Screenland, February 1931, 88.

${ }^{20}$ See also the useful work on fan magazines in Miriam Hansen, Babel and Babylon: Spectatorship in American Silent Film (Cambridge, MA: Harvard University Press, 1994); Kathryn H. Fuller, At the Picture Show: Small Town Audiences and the Creation of Movie Fan Culture (Charlottesville: University of Virginia Press, 2001); Richard deCordova, Picture Personalities: The Emergence of the Star System in America (Urbana: University of Illinois Press, 2001); and Anthony Slide, Inside the Hollywood Fan Magazine: A History of Star Makers, Fabricators and Gossip Mongers (Jackson: University Press of Mississippi, 2010).

${ }^{21}$ Slide, Inside the Hollywood Fan Magazine, 3.

22 The title change from Motion Picture Story Magazine, announced in February 1914 (172), was accomplished in the March 1914 issue.

${ }^{23}$ March 1914 for Photoplay, October 1914 for Motion Picture Magazine. Motion Picture Classic began with this model in 1915.

${ }^{24}$ See Photoplay July 1913. Covers after this reverted to the "scene from a movie" format until the following year.

${ }^{25}$ See deCordova, Picture Personalities.

${ }^{26}$ Ibid., 127-28.

27 “Fan Mags Get Nasty for Sales,” Variety, October 13, 1931, 3.

${ }^{28}$ DeCordova, Picture Personalities, 117-51.

${ }^{29}$ See, for example, "Gold Diggers in Hollywood," Screenland, April 1922; "Why Men Fall in Love with Movie Actresses," Photoplay, February 1925; "Do They 
Marry for Money?," Photoplay, December 1926; and "There's Something about an

Actress That Attracts Wealthy and Titled Men," Motion Picture, January 1927.

30 “Why Can’t Stars Stay Married?," Screenland, January 1924; "Why Many Movie

Marriages Fail," Photoplay, October 1925; "How about Mary \& Doug?," Photoplay,

August1930; and "Why Can’t They Stay Married?," Motion Picture, November 1930.

${ }^{31}$ Articles continued to suggest mercenary motives with "How Norma Shearer Got

What She Wanted," Photoplay, May 1931, and "Why Do Screen Beauties Marry

Plain Business Men?," Motion Picture, February 1934. The doomed Hollywood romance area seems to have proliferated, however: "Why Women Go Crazy over Clark Gable!," Photoplay, November 1931; “The High Price of Hollywood Love Making," Photoplay, January 1933; “'I Had to Leave John Gilbert'—Virginia Bruce,” Photoplay, April 1934; “The Real Truth about Lupe’s Break with Gary,” Modern Screen, January 1932; "The Exclusive Inside Story of the Joan-Doug Separation!," Modern Screen, May 1933; "Do Hollywood Husbands Trust Their Wives?," Motion Picture, August 1931; "Why the Gilbert-Claire Marriage Failed!," Motion Picture, November 1931; "Will Joan Crawford's Career Wreck Her Marriage?,” Motion Picture, September 1932; and "Carole Lombard Tells Why Hollywood Marriages Can't Succeed," Motion Picture, May 1934.

${ }^{32}$ See "Bargain Counter Mags," Variety, January 26, 1931, 56.

33 “"Stars at Their Worst' New Demand for Dailies, Fan Mags,” Variety, March 8, 1932, 3; and "Fan Photogs Tuff," Variety, August 1, 1933, 2.

34 “Fan Mag Royalty Out,” Variety, October 17, 1933, 3; James Cunningham, “Asides and Interludes," Motion Picture Herald, November 25, 1933, 64; and Dick Moss, "More on 'Antiquated Ballyhoo," Motion Picture Herald, December 16, 1933, 68.

${ }^{35}$ Advertisement, Motion Picture Herald, December 31, 1932, 49. 
${ }^{36}$ See inside front cover, Motion Picture Herald, May 27, 1933.

${ }^{37}$ Tradeviews, Hollywood Reporter, June 2, 1933, 1.

${ }^{38}$ Ibid.

${ }^{39}$ Ibid.

40 There is an unexplained gap in this coverage between March 7 and April 26, 1934.

${ }^{41}$ Reviewing the Fan Magazines, Hollywood Reporter, June 2, 1933, 11.

${ }^{42}$ Charlie Keil, "Cary Grant and Katharine Hepburn: Domesticated Mavericks," in What Dreams Were Made Of: Movie Stars of the 1940s, ed. Sean Griffin (New Brunswick, NJ: Rutgers University Press, 2011), 192-216.

${ }^{43}$ See, for example, James M. Fiddler, "Is Hepburn a Movie Bubble?," Screenland, September 1933, referenced in Reviewing the Fan Mags, Hollywood Reporter, August 2, 1933, 4; and M. Oakley Christoph, “Oh, Hepburn, Behave!,” Picture Play, May 1934, referenced in Reviewing the Fan Mags, Hollywood Reporter, April 23, 1934, 6.

${ }^{44}$ Slide, Inside the Hollywood Fan Magazine, 77.

${ }^{45}$ There are signs, I would argue, that the reviewer's voice was a feminine one; of the uninspired stories in July 1933's Modern Screen, the reviewer said they "will attract about as much attention as a puffed sleeve" (Reviewing the Fan Mags, Hollywood Reporter, June 10, 1933, 2). This comment, coming around fourteen months after Letty Lynton (released May 1932) started a widespread fad for white organdy dresses with huge puffed sleeves, sounds like a fashion-savvy put-down and an unlikely reference point for a male author in 1933. Similarly, another Reviewing column celebrated "Sex Appeal in the Clothes You Wear," which it called "a swell Spring feature" in April 1934's Motion Picture (Reviewing the Fan Mags, Hollywood 
Reporter, March 16, 1934, 6). These sartorial references are not definitive proof of female gender, of course, but seem to me suggestive of it.

${ }^{46}$ Elizabeth Wilson, “Their Beach Behavior,” Silver Screen, July 1933, in Reviewing the Fan Mags, Hollywood Reporter, June 10, 1933, 2.

${ }^{47}$ Screen Play, February 1934, in Reviewing the Fan Mags, Hollywood Reporter, January 23, 1934, 11.

${ }^{48}$ Reviewing the Fan Mags, Hollywood Reporter, June 2, 1933, 11.

${ }^{49}$ Elizabeth Wilson, Silver Screen, December 1933, in Reviewing the Fan Mags, Hollywood Reporter, November 16, 1933, 4.

${ }^{50}$ Reviewing the Fan Mags, Hollywood Reporter, December 11, 1933, 7.

${ }^{51}$ Silver Screen, January 1934, in Reviewing the Fan Mags, Hollywood Reporter, December 14, 1933, 7.

${ }^{52}$ Movie Mirror, April 1934, Reviewing the Fan Mags, Hollywood Reporter, March $16,1934,6$

${ }^{53}$ Reviewing the Fan Mags, Hollywood Reporter, July 15, 1933, 2.

${ }^{54}$ W. R. Wilkerson, Tradeviews, Hollywood Reporter, June 2, 1933, 1.

${ }^{55}$ Screenland, September 1933, in Reviewing the Fan Mags, Hollywood Reporter, August 2, 1933, 4.

${ }^{56}$ Picture Play, August 1933, Reviewing the Fan Mags, Hollywood Reporter, July 5, 1933, 6.

${ }^{57}$ Reviewing the Fan Mags, Hollywood Reporter, July 1, 1933, 4.

${ }^{58}$ Reviewing the Fan Mags, Hollywood Reporter, June 10, 1933, 2.

${ }^{59}$ Reviewing the Fan Mags, Hollywood Reporter, June 23, 1933, 2.

${ }^{60}$ Movies, September-October 1933, in Reviewing the Fan Mags, Hollywood Reporter, October 26, 1933, 7. 
${ }^{61}$ Reviewing the Fan Mags, Hollywood Reporter, February 12, 1934, 8.

${ }^{62}$ Reviewing the Fan Mags, Hollywood Reporter, November 13, 1933, 8.

${ }^{63}$ Reviewing the Fan Mags, Hollywood Reporter, November 15, 1933, 6.

${ }^{64}$ Gilbert Seldes, The Seven Lively Arts (New York: Harper and Brothers, 1924).

${ }^{65}$ Emily Post, Etiquette (New York: Funk and Wagnalls, 1934), 682-84.

${ }^{66}$ Ibid., $514-18$.

${ }^{67}$ Ibid., 514.

${ }^{68}$ Ibid., 515.

${ }^{69}$ Roland Marchand's book, Advertising the American Dream: Making Way for Modernity, 1920-1940 (Berkeley: University of California Press, 1992), contains further interesting information about the interconnections between good taste and class. The author details the work of advertising men from the 1920s onward, indicating how they felt the slogans and products on which they worked were beneath them ("it was degrading to live at the whim of mass consumers," 69) but also how they saw elevating the tastes of these masses as part of their responsibilities, viewing themselves as "cultivated imposers of good taste from above" (130). The reviewer clearly shares some of the beliefs of this elite group of educated advertising men. ${ }^{70}$ It is difficult to find reliable subscription figures. The Hollywood Reporter itself, in an article on the "Fan Mag Drop" (May 25, 1933, 1, 7), gave the following numbers for these titles: Modern Screen, 556,421; Photoplay, 461,842; Motion Picture, 456,002; Picture Play, 341,218; and Screen Play, 211,132. The piece does not mention Movie Mirror, nor does it provide the source of its data. N. W. Ayer \& Son's American Newspaper Annual and Directory compiled and printed annual lists for all American publications, and the figures it has for the same year are noticeably lower: 
Modern Screen, 474,875; Photoplay, 391,900; Motion Picture, 324,819; Picture Play, 253,383; Screen Play, 214,889; and Movie Mirror, 150,000. See N.W. Ayer \& Son's American Newspaper Annual and Directory (1934).

${ }^{71}$ Reviewing the Fan Mags, Hollywood Reporter, June 3, 1933, 2.

72 John L. Haddon, “Lil vs Hedda—What a 'Battle,"” Motion Picture, July 1933, 58, $87-88$.

${ }^{73}$ Reviewing the Fan Mags, Hollywood Reporter, June 8, 1933, 2.

${ }^{74}$ Meyer Levin, “Footing Jimmy’s Bill,” Photoplay, July 1933, 52-53.

${ }^{75}$ Advertisement, Hollywood Reporter, March 16, 1934, 6.

${ }^{76}$ Dorothy Wooldridge, "Can She Beat the Chaplin Jinx?,” Modern Screen, December 1933, 66-67, 107-9.

${ }^{77}$ Ibid., 67.

${ }^{78}$ Ibid., 109.

79 Jeanne de Kolty, “The Strange Case of Miss Morley,” Picture Play, January 1934, $30-31,55$.

${ }^{80}$ Reviewing the Fan Mags, Hollywood Reporter, December 13, 1933, 6.

${ }^{81}$ De Kolty, “The Strange Case of Miss Morley,” 31.

${ }^{82}$ Ibid.

${ }^{83}$ Ibid., 55.

${ }^{84}$ Reviewing the Fan Mags, Hollywood Reporter, April 4, 1934, 6.

${ }^{85}$ Katharine Albert, “I’m a Terrible Person,” Modern Screen, April 1934, 28.

${ }^{86}$ Myrtle Gebhart, “As They See Themselves,” Picture Play, July 1930, 83-86, 114.

${ }^{87}$ Muriel Babcock, “Their Million Dollar Defects," Silver Screen, October 1931, 2223,64 .

${ }^{88}$ Albert, "I'm a Terrible Person,” 29. 
${ }^{89}$ Ibid.

${ }^{90}$ Reviewing the Fan Mags, Hollywood Reporter, April 4, 1934, 6.

${ }^{91}$ Reviewing the Fan Mags, Hollywood Reporter, July 5, 1933, 6.

${ }^{92}$ Frank Pope, Tradeviews, Hollywood Reporter, July 3, 1934, 1, 4.

${ }^{93}$ Ibid., 1.

${ }^{94}$ Mary Desjardins, “'Fan Magazine Trouble’: The AMPP, Studio Publicity Directors, and the Hollywood Press, 1945-1952," Film History 26, no. 3 (2014): 29-56.

${ }^{95}$ Frank Pope, Tradeviews, Hollywood Reporter, July 3, 1934, 4.

96 “Catholics on Warpath,” Hollywood Reporter, May 31, 1934, 1, 3.

${ }^{97}$ Ibid., 1.

${ }^{98}$ W. R. Wilkerson, Tradeviews, Hollywood Reporter, May 31, 1934, 1.

99 “Cardinal Bans All Pix,” Hollywood Reporter, June 9, 1934, 1.

100 “New Plan to Legislate Morals into Pictures," Hollywood Reporter, June 11, 1934, $1,2$.

${ }^{101}$ W. R. Wilkerson, Tradeviews, Hollywood Reporter, June 14, 1934, 1, 4.

102 “Actors Resent Slurs,” Hollywood Reporter, June 14, 1934, 1.

${ }^{103}$ W. R. Wilkerson, Tradeviews, Hollywood Reporter, June 15, 1934, 1.

104 “Catholic Boycott Spreads Rapidly,” Hollywood Reporter, June 15, 1934, 1, 3.

${ }^{105}$ Frank Pope, Tradeviews, Hollywood Reporter, June 18, 1934, 1.

106 “Jewish Conference Joins War on Dirt,” Hollywood Reporter, June 19, 1934, 1.

107 “Hays Office Orders 'Born To Be Bad' Retakes,” Hollywood Reporter, June 19, $1934,3$.

108 “New Hays Plan to Clean Up Pictures,” Hollywood Reporter, June 19, 1934, 4.

${ }^{109}$ Reviewing the Fan Mags had an irregular publishing schedule; seemingly, the column was printed whenever there were both space and copy available. The average 
gap between appearances of the column was only a few days, with a nine-day hiatus occurring three times, ten once, eleven once, and thirteen once. The longest interruption, of twenty days, occurred between February 12 and March 7, 1934. ${ }^{110}$ Frank Pope, Tradeviews, Hollywood Reporter, June 20, 1934, 1, 2.

${ }^{111}$ W. R. Wilkerson, Tradeviews, Hollywood Reporter, June 2, 1933, 1.

${ }^{112}$ Frank Pope, Tradeviews, Hollywood Reporter, June 20, 1934, 2.

113 “Fan Mags Promise to Be Good: Will Cut Writers," Hollywood Reporter, August $16,1934,1$.

${ }^{114}$ It was part 2 of this "heart-breakingly truthful Hollywood story." "I Have Been Kept by a Movie Star,” Modern Screen, December 1934, 42-43, 105-6.

115 “The Low Down,” Hollywood Reporter, June 29, 1934, 2.

Tamar Jeffers McDonald is Reader in Film at the University of Kent. She is the author of Romantic Comedy: Boy Meets Girl Meets Genre (Columbia University Press, 2007) and Hollywood Catwalk: Exploring Costume and Transformation in American Film (I. B. Tauris, 2010). Virgin Territory: Representing Sexual Inexperience In Film, her edited collection on filmic presentations of virginity, was published in 2010 by Wayne State University Press. Her research interests include film costume, romantic comedy, performance and movie magazines, topics which coalesced in her 2013 publication, Doris Day Confidential: Hollywood, Sex and Stardom. This explored the myth of the "forty year old virgin" attached to Day, locating its origins in the very movie magazines that condemned her for playing the role. Her most recent monograph is an in-depth analysis of When Harry Met Sally... published by the British Film Institute (2015). She is currently co-editing a collection on fan magazines for Iowa University Press. 